\title{
Salt efflorescence in historic wooden buildings
}

\author{
Emilio Catelli ${ }^{*}$, Florinel-Gabriel Bănică ${ }^{1}$ and Ana Bănică
}

\begin{abstract}
Efflorescence and subflorescence are frequent phenomena occurring in buildings of porous inorganic materials such as bricks, stone, and concrete. Since the above phenomena have detrimental effects, they were the subject of detailed physicochemical investigations. Efflorescence on wooden material was commonly observed on collection artefacts treated with preservatives such as inorganic salts or organic pesticides. Occurrence of efflorescence in historical wooden buildings was less studied although it could cause serious conservation concerns. This paper describes an examination of chemical and mineralogical composition of salt efflorescence in wooden buildings. In situ analysis by X-ray fluorescence spectrometry was followed by investigation of plain efflorescence by infrared spectrometry, X-ray diffraction, electron microscopy, and electron probe microanalysis. Quantitative analysis of purified efflorescence was performed by plasma atomic emission spectrometry, ion chromatography and absorption spectrophotometry. In addition, depth-profiling of characteristic ions in wood was performed. The objects of study were a series of log houses of the Sverresborg Trøndelag Folk Museum in Trondheim, Norway. It was found that the efflorescence in these buildings includes a series of metal ions, the most abundant being $\mathrm{Al}^{3+}, \mathrm{Mg}^{2+}, \mathrm{Zn}^{2+}, \mathrm{K}^{+}, \mathrm{Na}^{+}$, and $\mathrm{Fe}^{2+}$. In addition the ammonium ion is present in a large amount. The single detected anion is sulfate. Actually, the efflorescence consists of a mixture of simple and double sulfate salts of alum and Tutton's compound types. Identified Tutton's compounds are mohrite $\left(\left(\mathrm{NH}_{4}\right)_{2} \mathrm{Fe}\left(\mathrm{SO}_{4}\right)_{2} \cdot 6 \mathrm{H}_{2} \mathrm{O}\right)$, ammonium zinc sulfate hexahydrate $\left.\left(\left(\mathrm{NH}_{4}\right)_{2} \mathrm{Zn}\left(\mathrm{SO}_{4}\right)_{2} \cdot 6 \mathrm{H}_{2} \mathrm{O}\right)\right)$, and boussingaultite $\left.\left(\left(\mathrm{NH}_{4}\right)_{2} \mathrm{Mg}\left(\mathrm{SO}_{4}\right)_{2} \cdot 6 \mathrm{H}_{2} \mathrm{O}\right)\right)$. Among the alums, both tschermigite $\left(\mathrm{NH}_{4} \mathrm{Al}\left(\mathrm{SO}_{4}\right)_{2} \cdot 12 \mathrm{H}_{2} \mathrm{O}\right)$, and potassium alum $\left.\left(\mathrm{KAl}\left(\mathrm{SO}_{4}\right)_{2} \cdot 12 \mathrm{H}_{2} \mathrm{O}\right)\right)$ were detected. The composition of efflorescence suggests that the wooden material was treated with a blend of sulfate salts $\left(\left(\mathrm{NH}_{4}\right)_{2} \mathrm{SO}_{4}, \mathrm{Al}_{2}\left(\mathrm{SO}_{4}\right)_{3} \cdot 18 \mathrm{H}_{2} \mathrm{O}, \mathrm{MgSO}_{4} \cdot 7 \mathrm{H}_{2} \mathrm{O}, \mathrm{FeSO}_{4} \cdot 7 \mathrm{H}_{2} \mathrm{O}, \mathrm{ZnSO}_{4} \cdot 7 \mathrm{H}_{2} \mathrm{O}\right.$, and $\left.\mathrm{Na}_{2} \mathrm{SO}_{4} \cdot 10 \mathrm{H}_{2} \mathrm{O}\right)$ ) for protection against fire and biological degradation. The efflorescence appeared as a consequence of water leakage through the roof that led to the dissolution of the salts contained in the wood, followed by evaporation and salt crystallization at the surface in the form of double sulfate salts. Although the occurrence of efflorescence in this case was accidental, a natural and more frequent cause of efflorescence could be the deliquescence of inorganic preservatives impregnated in the wood.
\end{abstract}

Keywords: Wooden buildings, Wood degradation, Efflorescence, Subflorescence, Wood preservation, Archaeological wood, Flame retardants, Tutton's compounds, Alums

Stony are the work of Nature, and wooden are the fashionings of man; or at least they used to be while the natural order of things prevailed in the world [1]

\footnotetext{
*Correspondence: emilio.catelli@ntnu.no

1 Department of Chemistry, Faculty of Natural Science and Technology,

NTNU (Norwegian University of Science and Technology),

7491 Trondheim, Norway

Full list of author information is available at the end of the article
}

\section{Background}

Wood was, and is still, one of the most common materials connected to human civilization. However, as an organic material, wood is vulnerable to both blaze and biological degradation. Hence, during the industrial era, various methods for protection against the above risks were developed. Although protection of wooden building material is currently a largely settled problem [2-4] challenges still arise when dealing with preservation of wooden heritage artifacts that undergone deterioration 
before being uncovered and stored under appropriate conditions. Conservation of wooden artworks is mostly based on treatment with chemicals to protect against fire and biological degradation. If the cellulose network is largely damaged, consolidation of the surviving fragile structure is also attempted [5]. Unfortunately, preservation technologies applied in the past caused often subsequent problems for both the conservation and health. Well known are in this respect the health hazards arising from treatment with pesticides and the associated decontamination issues $[6,7]$.

Before the advent of pesticide, wood artworks were protected by treatment with inorganic biocides and inorganic flame retardants. As a side effect, certain inorganic preservatives, such as boric acid, borax, and potassium alum, may give rise to efflorescence with detrimental effect not only on the appearance but also on the longterm stability of the wood structure [5].

In this work, efflorescence denotes the precipitation of salts from a supersaturated solution included in a porous substratum when the liquid-vapor interface remains at the surface of the porous medium. When the evaporation occurs within a porous medium, the process is termed as subflorescence or crypto-florescence [8]. Frequently, efflorescence also denotes the product of the efflorescence process. The above definition of efflorescence is largely employed in building technology science but it differs from that accepted in chemistry [9].

Salt efflorescence is a common degradation process in masonry materials such as concrete and brick and was studied extensively $[8,10,11]$. Conversely, investigations of efflorescence in wooden buildings are scarce. It is worth mentioning in this respect the survey of efflorescence in a series of wooden shrines in Korea [12]. In this case, efflorescence, which produced painting exfoliation and bleaching phenomena, was put into relation with flame retardants contained in the wood.

This work introduces a protocol for the examination of salt efflorescence in historical wooden buildings with a focus on its chemical and mineralogical composition. The protocol combines in situ analysis by X-ray fluorescence spectrometry, laboratory tests on both plain and purified efflorescence, and depth-profiling of non-biogenic chemicals in the wood materials. Ensuing data allow assessing the cause of efflorescence, its impact on the building conservation, health hazards, and the appraisal of possible remediation techniques.

The application of this protocol is exemplified by the investigation of the efflorescence in eighteenth century pine log buildings from the mining city of Røros, Norway, which were relocated to the Sverresborg Trøndelag Folk Museum in Trondheim, Norway, in 1917 [13, 14]. These buildings are designated Aspaas House, Tronshart House, and Travelers' Stable. The Aspaas House (Fig. 1) is a threestore $\log$ house in the baroque style which belonged to a middle class owner. The Tronshart House is a modest lower class house, composed of a room at the ground floor and another one in the attic. In both buildings, indoor efflorescence occurred, producing sparse deposits of translucent crystals on certain areas of the ceilings and the walls. There are no reliable information on the cause and the period when the efflorescence appeared. Although no efflorescence occurs in Travelers' Stable, this building was also investigated because it belongs to the same group.

\section{Experimental procedures}

\section{Outline of sampling and investigation protocol}

Investigation of the efflorescence process and products included four steps, namely (1) on site investigations and sampling; (2) laboratory investigation of plain efflorescence; (3) chemical analysis of recrystallized efflorescence; (4) depth-profiling of non-biogenic chemicals in the wooden material.

\section{On-site investigations and sampling}

X-ray fluorescence spectrometry (XRF) performed by means of a portable instrument was used for the identification of chemical elements on both efflorescence-coated and efflorescence-free areas.

Efflorescence samples were collected into plastic vials by means of a plastic scalpel from the ceiling and the wall of Aspaas House (denoted ASP1 and ASP2, respectively), and from Tronshart House. Besides, wood cores $(10 \mathrm{~cm}$ length and $0.5 \mathrm{~cm}$ diameter) were collected from both intact and efflorescence-coated areas in the Aspaas House using an increment borer. If present, the efflorescence was removed from the surface before collecting the core.

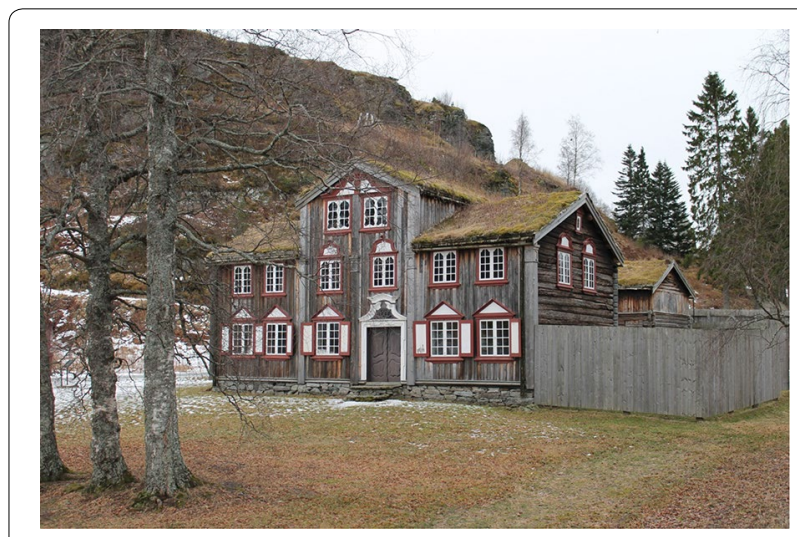

Fig. 1 North facade of the Aspaas House at the Sverresborg Trøndelag Folk Museum (Trondheim, Norway) 


\section{Laboratory investigation of plain efflorescence}

This step included (1) morphology investigation by optical microscopy and back-scattered electrons imaging (BSE); (2) identification and mapping of chemical elements by electron probe microanalysis (EPMA); (3) identification of molecular species by Fourier transforminfrared spectrometry (FT-IR); (4) mineralogical analysis by X-ray diffraction (XRD); (5) confirmatory qualitative micro-chemical tests.

\section{Analysis of recrystallized efflorescence}

Portions of efflorescence samples were dissolved in purified water and filtered through red dot (medium dense, medium fast filtering) quantitative filter paper. The filtrate was centrifuged at $8{ }^{\circ} \mathrm{C}$ for $2 \mathrm{~h}$ at $20,000 \mathrm{rpm}$. The supernatant was collected with a Pasteur pipette and subjected to recrystallization at room temperature and normal pressure in order to mimic the conditions under which the efflorescence developed. Quantitative analysis of recrystallized material was performed after dissolving $3-5 \mathrm{mg}$ in $25.0 \mathrm{ml}$ purified water, followed by element determination by inductively-coupled plasma atomic emission spectrometry (ICP-AES), anion determination by ion chromatography (IC), and ammonium determination by absorption spectrophotometry.

\section{Depth-profiling of non-biogenic chemical substances in wood} Core samples were divided into five $2 \mathrm{~cm}$ sections. Each section was weighed, gently crushed and subjected to salt leaching by shaking in $25 \mathrm{ml}$ purified water for 2 days. Finally, the solution was purified by filtration as above, and analyzed for ammonium and sulfate ions.

\section{Methods}

All chemicals were of reagent-grade quality. Purified water (18 $\mathrm{M} \Omega \mathrm{cm}^{-1}$ resistivity) was obtained by a MiliQ (Millipore) system. Centrifugation was done using a Sorvall ${ }^{\circledR}$ C-Plus centrifuge. Microscope investigation was performed with an AmScopeTM ZM-1T binocular stereomicroscope. On-site XRF analyses was performed under helium purge by a portable NITON XL3t 900 spectrometer (Thermo Fisher Scientific) operated in the mining mode. Regression analysis of XRF data was performed by means of the Minitab statistical software package. A Hitachi S-3400 N scanning electron microscope equipped with an X-Max Energy Dispersive X-Ray Analyzer (Oxford Instruments) was used for both BSE imaging and EPMA investigations (acceleration voltage, $15-20 \mathrm{kV}$; lifetime $<30 \mathrm{~s}$ ). K X-ray series were recorded for all elements except zinc (L series). XRD was performed by a Bruker D8 Focus diffractometer using $\mathrm{Cu} \mathrm{K} \alpha$ radiation (tube operating parameters: $40 \mathrm{kV}$ and $40 \mathrm{~mA}$ ) and a LynxEye ${ }^{\mathrm{TM}}$ SuperSpeed detector.
The scanned interval was from $2 \theta=10^{\circ}$ to $35^{\circ}$ stepping at $0.010^{\circ}$ every $0.5 \mathrm{~s}$. Diffraction patterns were interpreted by the PDF (ICDD) in-build library of standard compounds. Transmission infrared spectra were collected using an AVATAR 330 FT-IR spectrometer from Thermo Fisher Scientific. Spectra were obtained as $\mathrm{KBr}$ pellets containing $1 \mathrm{mg}$ sample to $100 \mathrm{mg} \mathrm{KBr}$ (FT-IR grade $\geq 99 \%$, Sigma Aldrich Inc.) by averaging 32 scans for the signal and the background, with a spectral resolution of $4 \mathrm{~cm}^{-1}$. Quantitative analyses by ICP-AES were done by an Optima 4300DV instrument (Perkin Elmer). Anion determination by IC was performed with a Dionex DX-120 instrument. The concentration of ammonium ion was determined by absorption spectrophotometry according to standard methods $[15,16]$.

The accuracy of the quantitative analysis was checked by means of the ionic charge balance according to the guidelines in $[17,18]$. Briefly, total cation and total anion charges $\left(E_{c}\right.$ and $E_{a}$, respectively, in meq $\left.\mathrm{g}^{-1}\right)$ were calculated first as follows:

$$
E_{t}=\sum_{i} w_{i}\left|z_{i}\right| M_{i}^{-1}
$$

where $E_{t}$ stands for either $E_{c}$ or $E_{a}, w_{i}$ is the content (in $\mathrm{g} \mathrm{g}^{-1}$ ) of the ion $i$ of charge $z_{i}$ in the solid sample and $M_{i}$ is the molar mass of the ion $i$. The charge imbalance $\left(B_{z}\right.$, in percent) was calculated as:

$$
B_{z}=100\left(E_{c}-E_{a}\right) A^{-1}
$$

where $A$ is the average of cation and anion total charges in absolute values:

$$
A=\left(E_{c}+\left|E_{a}\right|\right) / 2
$$

Qualitative microchemical tests were conducted according to well-known procedures [19] in order to assess the presence of ammonium (Nessler's test), sulfate (barium chloride test) chloride (silver nitrate test), and carbonate (acid test) in the plain efflorescence material.

\section{Results}

\section{On-site investigations}

Efflorescence in Aspaas House occurs on certain areas on walls and ceilings in the 2nd and 3rd floor but is absent at the ground floor. In Tronshart House, efflorescence is coating the entire southern wall in the attic and also appears on the upper quarter of the wall below, in the ground floor. Efflorescence location excludes the possibility of salt transfer from the ground by water infiltration. The crystal deposit is not compact but appears as a pattern of isolated crystalline formations (Fig. 2). This morphology is typical of efflorescence growth [20].

Identification of chemical elements in efflorescence was performed by XRF spectrometry. XRF investigations 


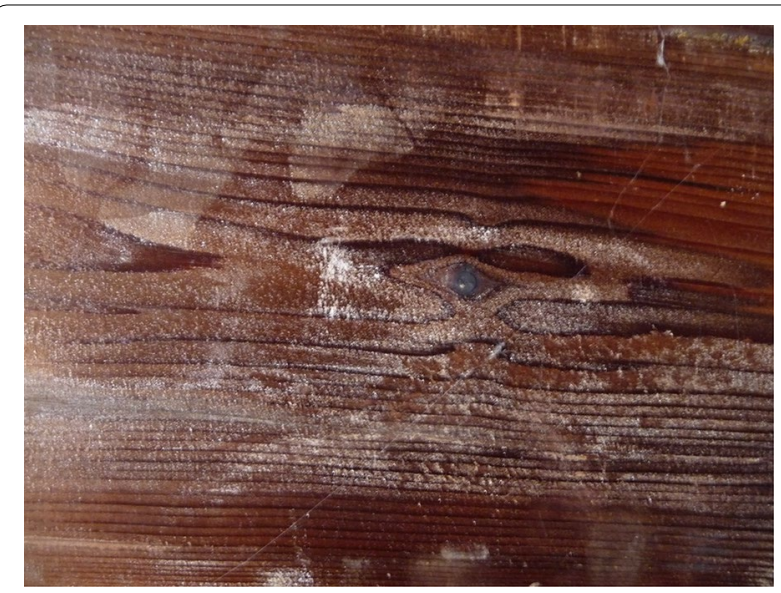

Fig. 2 Efflorescence on the ceiling of Aspaas House in the second floor

encompassed a series of non-painted wallboards and log spots in Aspaas House, Tronshart House and Travelers' Stable and included original building materials with and without efflorescence. Besides, logs installed as replacements during rehabilitation in 2002 were also tested and used as blank specimens.

Recently-installed logs display only elements commonly present in wood [21], namely, magnesium (about $0.1 \%$ ), potassium (0.01-1.0\%), calcium (about $0.15 \%$ ), and silicon $(0.2-0.3 \%)$. Besides the above elements, the original wooden material displays aluminum, zinc, iron, manganese, and copper. Magnesium and potassium are present in the original material at concentrations much higher than in blanks, which demonstrates that these elements are mainly of non-biogenic origin. Besides, the sulfur $\mathrm{K} \alpha$ line is evident in most of the spectra collected from the original material but the sulfur content was not reported by the instrument probably due to the calibration procedure. The sulfur line is missing in all blanks spectra.

As stated in "Methods" section, the XRF instrument was operated in the mining mode. This is not suited for quantitative analysis of inorganic material included in an organic matrix (wood) and no better calibration mode was available. Therefore, it was preferred to consider further not the reported concentrations but the intensity of $\mathrm{K} \alpha$ lines of representative elements. It was assumed that the line intensity is proportional to the element concentration. Among the detected elements, sulfur, potassium, calcium, iron, and manganese were selected for further data analysis. The reason for this selection is the fact that these elements display $K \alpha$ lines clearly separated from the background in most of the tested spots. Aluminum and magnesium $\mathrm{K} \alpha$ lines are hardly detectable and these elements will be omitted in the comments below.
As a working hypothesis, it was assumed that the detected elements have a common origin, i.e., the same kind of salt is present all over in the investigated buildings. A common origin of elements can be proved by examining the correlation between element concentrations at various tested spots. As reported concentrations are not accurate, line intensities (in counts per second) were measured on each X-ray spectrum and correlations between line intensities of representative elements were examined. It was thus found that potassium-sulfur and manganese-sulfur linear correlations are statistically significant at a significance level $0.05(p<0.05)$. Data from all investigated buildings were included in the above test. The iron-sulfur linear correlation is also statistically significant but only for data from Aspaas House. This is explained by the absence of iron in most of the data sets collected in other buildings. Calcium line shows random variations and do not correlate with the sulfur line. Apparently, calcium is present mostly as a natural component of wood. From the above results it appears that at least sulfur, potassium, manganese and iron have a common origin and the efflorescence contains most probably sulfate salts. The common origin of the above elements allows considering them as indicators of salt presence.

The indicator elements are present at all efflorescencecoated spots. If the crystal deposit at a given spot is removed by brushing, line intensities of the indicator elements are reduced but are still much higher than in blanks. This implies that salts are present not only at the surface but also within the original wooden material.

Line intensities at an efflorescence-free spot are only slightly lower than those recorded at a nearby efflorescence-coated spot on the same building component. This is an additional evidence of the salt presence within the wood. Moreover, if the outdoor surface of an original log, which is exposed to weather, is considered, the content of each indicator elements is almost similar to that in the blanks. Hence, the inorganic compounds present in the wood are water-soluble and were washed out by precipitation from outdoor areas of the buildings. The absence of salt contamination on external surfaces proves also that the salts cannot originate from the environment.

Despite no visible efflorescence in Travelers' Stable, indicator elements were detected in this building as well. On a small portion of an original $\log$, from which a wood layer about $5 \mathrm{~mm}$ thick had been removed by carving (during a recent repair), the indicator elements were found at concentrations lower than on an intact spot on the same log. Therefore, the indicator elements are present not only at the surface of the material but also within a peripheral layer at least $5 \mathrm{~mm}$ thick.

In summary, XRF data demonstrated that the efflorescence contains a mixture of magnesium, potassium, zinc, 
iron, and aluminum salts (probably sulfates). A similar mixture was found at efflorescence-free spots nearby efflorescence-coated spots and also in certain efflorescence-free building elements. As XRF cannot detect light elements, the presence of such elements cannot be excluded and it remains to identify them by laboratory assays. Taking into account the aspect of efflorescencecoated areas, the efflorescence may be put in relation with water leakage through the roof sometime in the past.

\section{Investigations of plain efflorescence FT-IR spectrometry data}

The investigated efflorescence samples display similar bands (Fig. 3) which suggest similar chemical compositions as far as molecular species are concerned. Further data interpretation was conducted using the guidelines in [22-24].

As sulfur was found in the efflorescence by XRF, the presence of sulfate anion was first checked. The normal vibrations of the free sulfate ion in aqueous solutions are known to occur at the following wavenumbers $\left(\right.$ in $\left.\mathrm{cm}^{-1}\right)$ : $1105\left(v_{3}\right.$-asymmetric $\mathrm{S}-\mathrm{O}$ stretch), $983\left(v_{1}\right.$-symmetric $\mathrm{S}-\mathrm{O}$ stretch), 611 ( $v_{4}$-asymmetric $\mathrm{SO}_{4}^{2-}$ bending), and 450 ( $v_{2}$-symmetric $\mathrm{SO}_{4}^{2-}$ bending) [22]. However, in the crystal state, the normal modes may shift or split due to various interactions. The above modes can be identified in efflorescence spectra as follows; 1090 and $1170\left(v_{3}\right)$, $978\left(v_{1}\right), 611\left(v_{4}\right)$, and $457\left(v_{2}\right) \mathrm{cm}^{-1}$. The splitting of the $v_{3}$ band was noticed previously for certain double sulfate salts such as aluminium potassium sulfate dodecahydrate (potassium alum, $\mathrm{KAl}\left(\mathrm{SO}_{4}\right)_{2} \cdot 12 \mathrm{H}_{2} \mathrm{O}$ ) $[25,26]$ and Tutton's compounds, which have the general formula $\mathrm{M}_{2}^{\mathrm{I}} \mathrm{M}^{\mathrm{II}}\left(\mathrm{SO}_{4}\right)_{2} \cdot 6 \mathrm{H}_{2} \mathrm{O}$, where $\mathrm{M}^{\mathrm{I}}$ is a monovalent- and $\mathrm{M}^{\mathrm{II}}$ is a divalent cation [27-29]. Given the content in metal elements determined by XRF, the occurrence of double sulfate salts in the efflorescence appears as very likely.

As the presence of crystallization water is highly probable, water characteristic bands were searched using available data for solid water [22] and selected hydrated metal sulfates. Although the band at $3350 \mathrm{~cm}^{-1}$ rests within the region of $\mathrm{OH}$ group stretching in metal (II) sulfates hexahydrates [30], its assignation to water may be doubtful due to the intricate pattern in this zone. A more reliable assignation can be made for the water bands at 1620 (bending), and 918 and $687 \mathrm{~cm}^{-1}$ (libration) by analogy with potassium alum $[25,26]$.

Further, the ammonium ion was ascertained in the efflorescence samples. Besides the normal mode vibration frequencies of ammonium (3040 $\left(v_{1}\right), 1680\left(v_{2}\right), 3145$ $\left(v_{3}\right)$, and $1400\left(v_{4}\right) \mathrm{cm}^{-1}$ [22]), a series of lattice modes and combination bands appear in spectra of common salts such as ammonium chloride [31]. By analogy, the series of four shoulders between 3000 and $3200 \mathrm{~cm}^{-1}$ in Fig. 3 can be ascribed to the ammonium ion. Within this interval, the $v_{3}$ mode as well as three distinct combination bands occur in ammonium chloride [31] but are hardly visible in the sample spectrum due to overlapping by the water band at $3350 \mathrm{~cm}^{-1}$. A more consistent identification of ammonium ion can be done by bands in the region of $v_{4}$ (asymmetric bending mode) where three bands at 1398,1431 , and $1470 \mathrm{~cm}^{-1}$ can be clearly distinguished in the sample spectrum. The first two appear at similar frequency in ammonium chloride spectrum [31]. All of the above three bands can be retrieved in the spectra of ammonium-containing Tutton's salts such as $\left(\mathrm{NH}_{4}\right)_{2} \mathrm{Mg}\left(\mathrm{SO}_{4}\right)_{2} \cdot 6 \mathrm{H}_{2} \mathrm{O}$ [28] and $\left(\mathrm{NH}_{4}\right)_{2} \mathrm{Zn}\left(\mathrm{SO}_{4}\right)_{2} \cdot 6 \mathrm{H}_{2} \mathrm{O}$ [29] but are missing in the

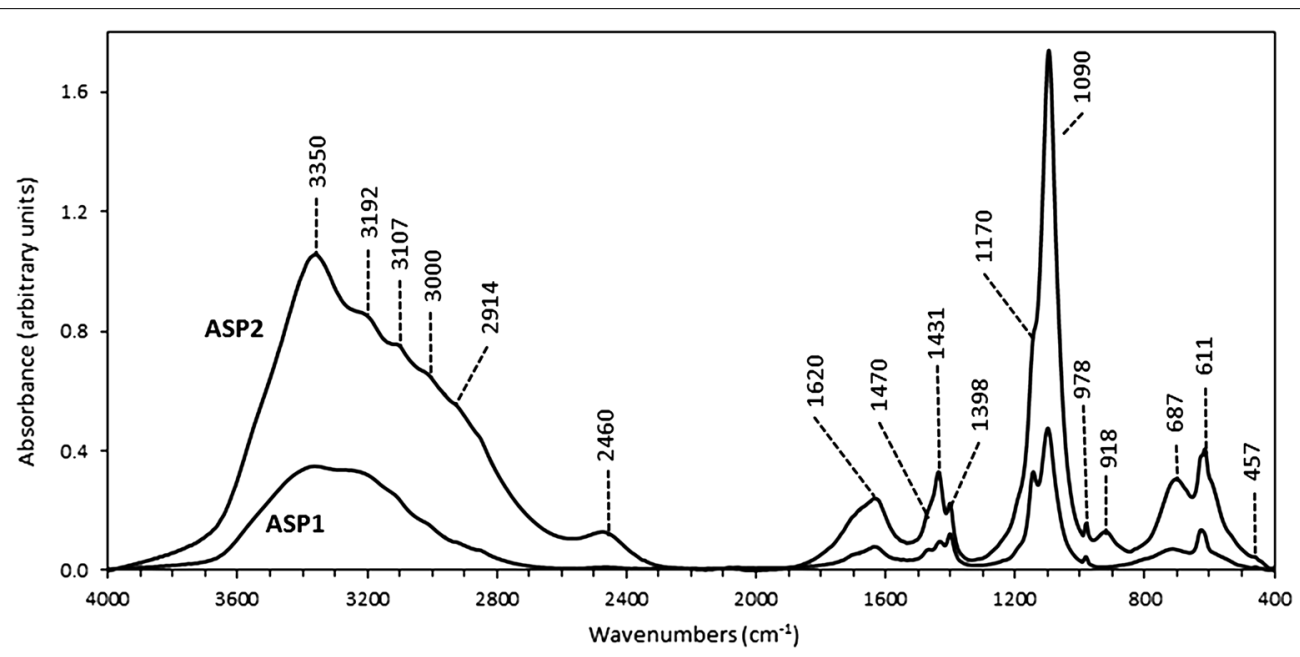

Fig. 3 Infrared spectra of the ASP1 and ASP2 specimens 
spectrum of an ammonium-less Tutton's salt such as $\mathrm{K}_{2} \mathrm{Mg}\left(\mathrm{SO}_{4}\right)_{2} \cdot 6 \mathrm{H}_{2} \mathrm{O}$ [28]. Except the band at $1470 \mathrm{~cm}^{-1}$, all ammonium bands in the sample spectrum are also present in the spectrum of aluminium ammonium sulfate dodecahydrate (ammonium alum, $\mathrm{NH}_{4} \mathrm{Al}\left(\mathrm{SO}_{4}\right)_{2} \cdot 12 \mathrm{H}_{2} \mathrm{O}$ ) [32]. Therefore, besides the metals detected by XRF, the ammonium ion is present in the efflorescence. It is likely that this ion is included as the monovalent ion in double sulfate salts of alum and Tutton's compound types. Besides, characteristic bands of nitrate and carbonate ions were not found in efflorescence spectra.

Qualitative microchemical tests for sulfate and ammonium gave positive results while chloride and carbonate ion were not detected in this way.

\section{$X R D$ investigations}

XRD patterns (Fig. 4) indicate the presence of two classes of double sulfate salts already mentioned, namely alums and Tutton's salts. Two alums, namely potassium alum and tschermigite (ammonium alum) were identified in both samples. They can be distinguished by the fine structure details in the diffraction pattern at $2 \theta$ about $20^{\circ}$ as shown in the expanded view in Fig. 4.

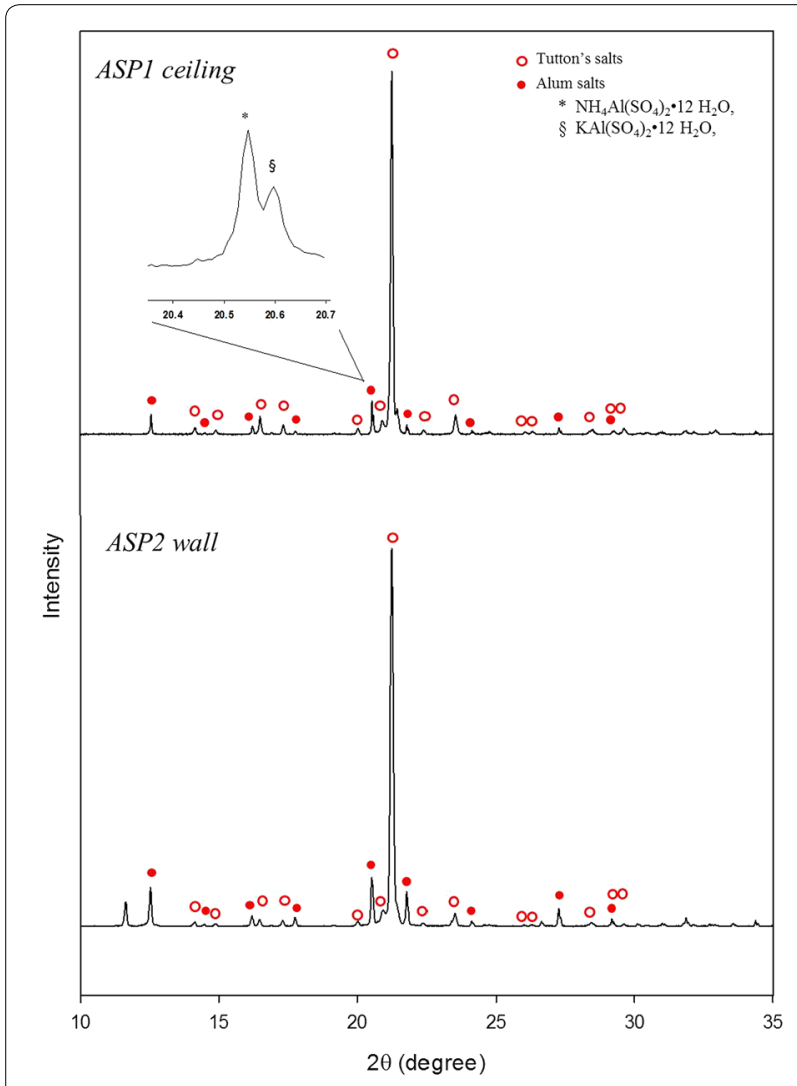

Fig. 4 XRD patterns of plain efflorescence specimens
Among various Tutton's salts, each of mohrite $\left(\left(\mathrm{NH}_{4}\right)_{2} \mathrm{Fe}\left(\mathrm{SO}_{4}\right)_{2} \cdot 6 \mathrm{H}_{2} \mathrm{O}\right)$, ammonium zinc sulfate hexahydrate $\left.\left(\left(\mathrm{NH}_{4}\right)_{2} \mathrm{Zn}\left(\mathrm{SO}_{4}\right)_{2} \cdot 6 \mathrm{H}_{2} \mathrm{O}\right)\right)$, and boussingaultite $\left.\left(\left(\mathrm{NH}_{4}\right)_{2} \mathrm{Mg}\left(\mathrm{SO}_{4}\right)_{2} \cdot 6 \mathrm{H}_{2} \mathrm{O}\right)\right)$ provide a good match with the sample XRD pattern but due to their similar crystal structure it is impossible to distinguish between them. Actually, a solution containing magnesium, zinc, and ammonium sulfate gives rise by crystallization to a series of compounds with the general formula $\mathrm{Zn}_{\mathrm{x}} \mathrm{Mg}_{(1-\mathrm{x})}\left(\mathrm{NH}_{4}\right)_{2}\left(\mathrm{SO}_{4}\right)_{2} \cdot 6 \mathrm{H}_{2} \mathrm{O}$ [33]. Mixed crystals of this type may also form at least a part of the efflorescence.

\section{BSE and EPMA investigations}

EPMA assays indicated oxygen, sulfur, aluminum, magnesium, and zinc as the most abundant elements. Iron and potassium are also present at significant levels whereas silicon and manganese and are present as minor components. These results are in agreement with XRF data.

Figure 5a displays a BSE image of efflorescence. In agreement with optical microscopy observations, it proves that the efflorescence consists of crystals of submillimeter size. Next images in Fig. 5 display the mapping of elements within the ASP1 specimen. Both oxygen and sulfur maps (Fig. 5b, c respectively) match very well the BSE image (Fig. 5a) proving an abundant occurrence and an even distribution of these elements within the efflorescence material. Other major elements, such as magnesium (d) and aluminium (e) display a similar trend. Less abundant elements ( $\mathrm{Zn}, \mathrm{Fe}$, and $\mathrm{K}$ ) are also uniformly spread within the specimen.

At a 10 times higher magnification, the distribution of the elements appears less even, as shown in Fig. 6. An interpretation of data in this figure can be done in the light of the FT-IR and XRD data above. Thus, sulfur and oxygen, which are present in the form of the sulfate ion, are found at each spot. At spots 1,2, and 3 , divalent metal ions $\left(\mathrm{Mg}^{2+}, \mathrm{Zn}^{2+}, \mathrm{Fe}^{2+}\right.$, and $\left.\mathrm{Mn}^{2+}\right)$ are accompanied by the monovalent potassium cation which suggest a that Tutton's salt occurs at each point. So, the lowest crystal is formed of zinc and iron Tutton's salts whereas at the upper part of the figure, magnesium Tutton's salt is mixed with similar salts of zinc and iron. Manganese seems to had been concentrated as a co-cation in magnesium-based Tutton's salts (spot 1 ) due to the similarity of ionic radia of the two ions [34]. Most probably, each of the above crystals is a mixed Tutton's salt crystal containing at least two different divalent cations. Since iron accompanies divalent cations, it can be inferred that it is present as the iron (II) ion. As far as the spots 4 are concerned, the elemental composition suggests that the pertinent 

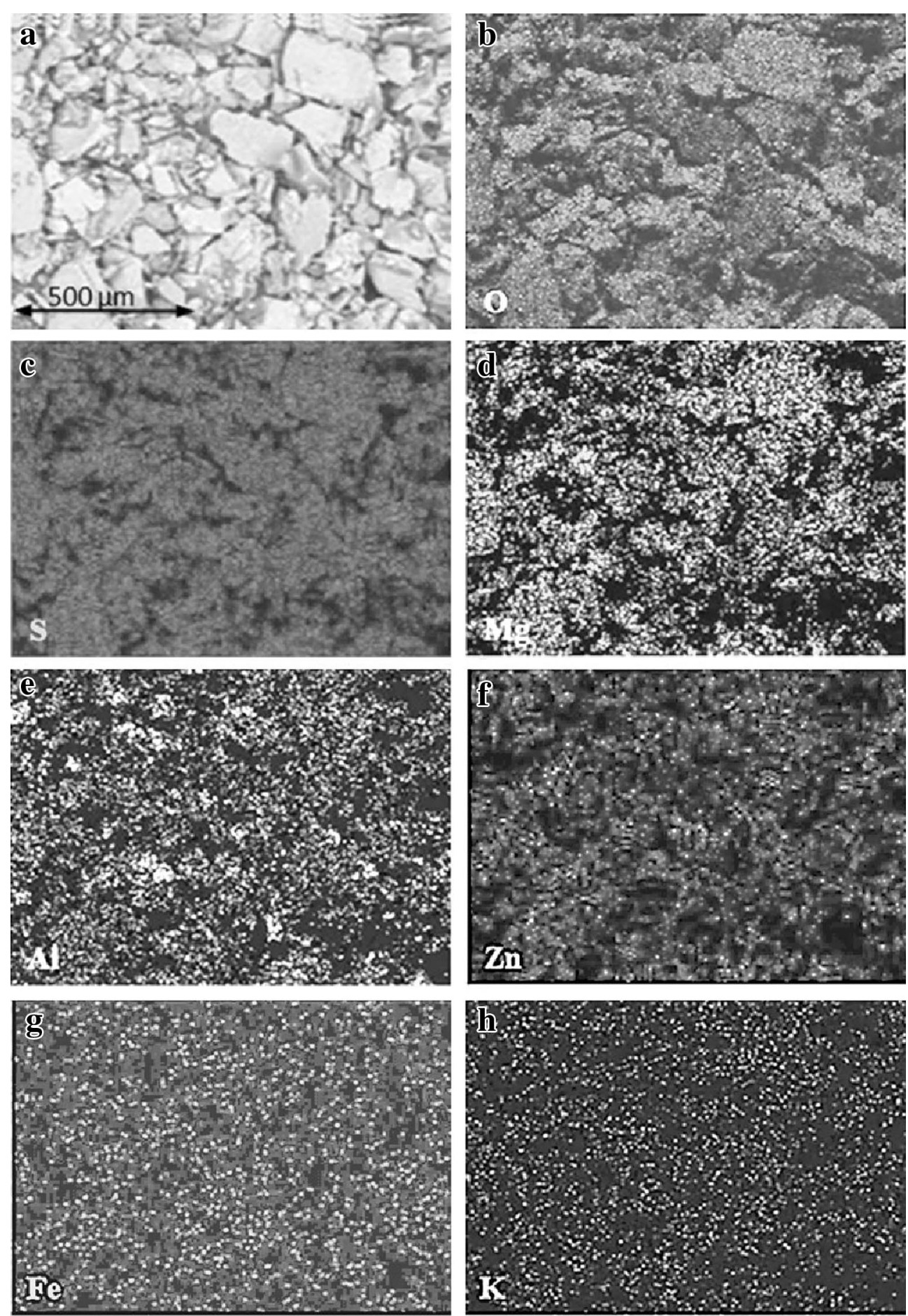

Fig. 5 EPMA elemental mapping for the ASP1 specimen. a BSE image. b-h mapping of elements indicated on each picture

crystal consists of aluminium alum. As ammonium was identified by FT-IR spectrometry, this ion is certainly included in both alums and Tutton's salt as a second monovalent ion, besides potassium.
In conclusion, the efflorescence contains a series of alums and Tutton's salts. In these double salts, the monovalent cations are ammonium and potassium. The single trivalent cation in alums is aluminium whereas Tutton's 


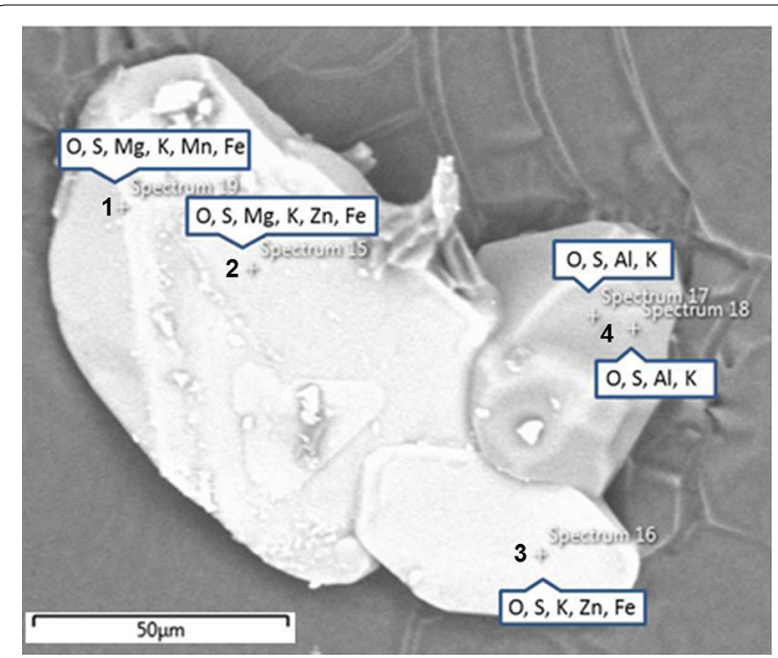

Fig. 6 Higher magnification BSE image and single-point elemental composition for the ASP1 sample

salt contains various divalent cations $\left(\mathrm{Mg}^{2+}, \mathrm{Zn}^{2+}, \mathrm{Fe}^{2+}\right.$, and $\left.\mathrm{Mn}^{2+}\right)$.

\section{Quantitative analysis of purified efflorescence}

Previous data proved that efflorescence from different locations in the Aspaas House are quite similar as far as the chemical composition is concerned. That is why, quantitative analytical investigations focused on the ASP2 sample. The XRD pattern of the purified ASP2 specimen was similar to that of the plain efflorescence, which indicates that laboratory recrystallization occurred mostly in the same way as the efflorescence process.

The results of the quantitative analysis of purified efflorescence are summarized in Table 1 which includes only the 8 most abundant cations that account for 98 mass \% of the total amount of cations. The contents (in $\mathrm{mg} \mathrm{g}^{-1}$ ) of the remaining metal elements are, as follows: manganese, 2.9; lead, 0.8; copper, 0.8; nickel, 0.2; cobalt, 0.1. The most abundant cations are ammonium, zinc, aluminum, and magnesium. Among the inorganic anions searched $\left(\mathrm{SO}_{4}^{2-}, \mathrm{NO}_{3}^{-}, \mathrm{NO}_{2}^{-}, \mathrm{HPO}_{4}^{2-}, \mathrm{F}^{-}, \mathrm{Cl}^{-}\right.$, and $\left.\mathrm{Br}^{-}\right)$, IC evidenced the sulfate anion only.

The accuracy of the quantitative analysis results was assessed by the charge balance calculated according to Eq. (2). The resulted imbalance was $-4.1 \%$ which falls within the limits of analysis errors.

In order to look for possible stoichiometric relationships, the cation content was recalculated in terms of mole percent with respect to the total number of moles of cations in the specimen. The results (Fig. 7) prove that ammonium accounts for about half of the total number of moles of cations. Next come aluminium and magnesium that are present in about similar mole
Table 1 Content of ions and double salts in recrystallized efflorescence from Aspaas House

\begin{tabular}{|c|c|c|c|}
\hline Ion & $\begin{array}{l}\text { lon } \\
\text { content, } \\
\mathrm{mg} \mathrm{g}^{-1}\end{array}$ & Possible sulfate salts & $\begin{array}{l}\text { Metal salt } \\
\text { content, } \\
\mathrm{mg} \mathrm{g}^{-1}\end{array}$ \\
\hline Sulfate $\left(\mathrm{SO}_{4}^{2-}\right)$ & 440.9 & & \\
\hline $\begin{array}{c}\text { Ammonium } \\
\left(\mathrm{NH}_{4}^{+}\right)\end{array}$ & 48.0 & & \\
\hline $\operatorname{Zinc}\left(\mathrm{Zn}^{2+}\right)$ & 26.6 & $\left(\mathrm{NH}_{4}\right)_{2} \mathrm{Zn}\left(\mathrm{SO}_{4}\right)_{2} \cdot 6 \mathrm{H}_{2} \mathrm{O}$ & 163.1 \\
\hline Aluminum $\left(\mathrm{Al}^{3+}\right)$ & 21.3 & $\begin{array}{l}\mathrm{NH}_{4} \mathrm{Al}\left(\mathrm{SO}_{4}\right)_{2} \cdot 12 \mathrm{H}_{2} \mathrm{O} \\
\mathrm{KAI}\left(\mathrm{SO}_{4}\right)_{2} \cdot 12 \mathrm{H}_{2} \mathrm{O}\end{array}$ & $\begin{array}{l}192.1 \\
172.7\end{array}$ \\
\hline $\begin{array}{l}\text { Magnesium } \\
\left(\mathrm{Mg}^{2+}\right)\end{array}$ & 17.3 & $\left(\mathrm{NH}_{4}\right)_{2} \mathrm{Mg}\left(\mathrm{SO}_{4}\right)_{2} \cdot 6 \mathrm{H}_{2} \mathrm{O}$ & 256.0 \\
\hline Potassium $\left(\mathrm{K}^{+}\right)$ & 14.2 & See Aluminum entry & \\
\hline Iron $\left(\mathrm{Fe}^{2+}\right)$ & 13.7 & $\left(\mathrm{NH}_{4}\right)_{2} \mathrm{Fe}\left(\mathrm{SO}_{4}\right)_{2} \cdot 6 \mathrm{H}_{2} \mathrm{O}$ & 92.6 \\
\hline Sodium $\left(\mathrm{Na}^{+}\right)$ & 7.4 & $\mathrm{Na}_{2} \mathrm{SO}_{4} \cdot 10 \mathrm{H}_{2} \mathrm{O}$ & 103.9 \\
\hline Calcium $\left(\mathrm{Ca}^{2+}\right)$ & 4.6 & $\mathrm{CaSO}_{4} \cdot 2 \mathrm{H}_{2} \mathrm{O}$ & $\begin{array}{r}19.6 \\
\text { Sum } 1025.7\end{array}$ \\
\hline
\end{tabular}

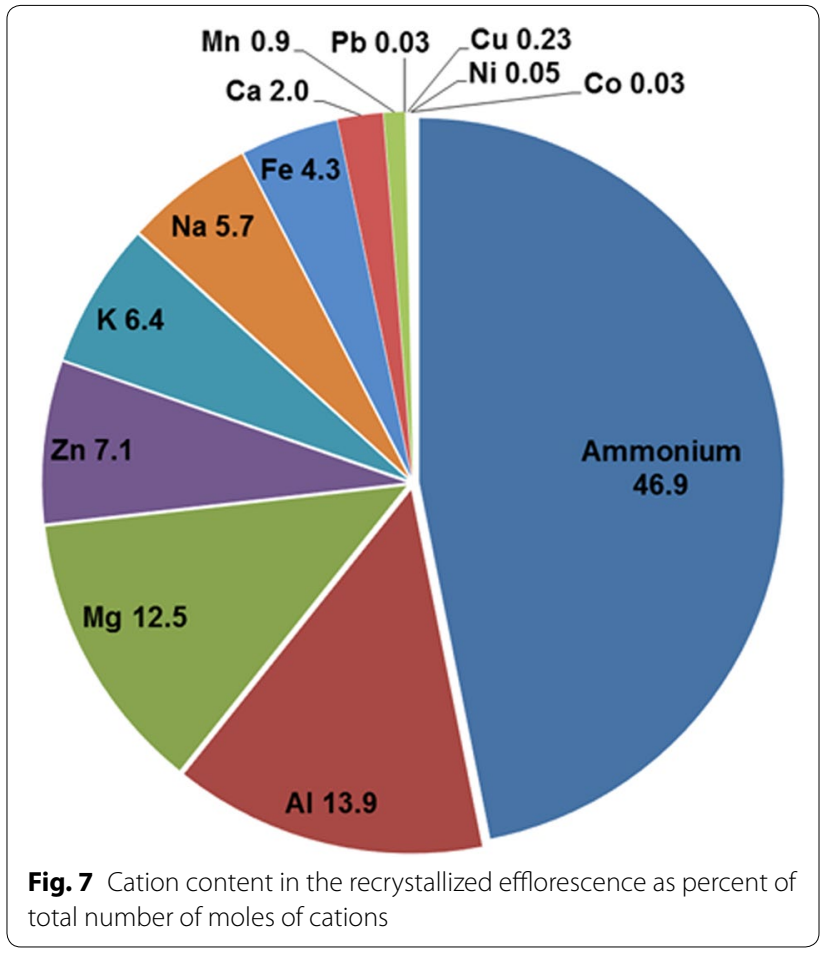

fractions, while zinc content represents approximately half of the aluminium one. Sodium, potassium, and iron are present at even lower concentrations whilst the contribution of minor constituents such as calcium, manganese and copper is less than $3 \%$ of the total cations content.

Taking into consideration the stoichiometric relationships, it was attempted to infer the contents of double sulfate salts that may occur in the recrystallized material. 
To this end, it was assumed that aluminium is present as potassium alum whereas $\mathrm{Mg}^{2+}, \mathrm{Zn}^{2+}$, and $\mathrm{Fe}^{2+}$ are included in Tutton's compounds with ammonium as the second ion. Supposed salts, as well as salt contents calculated under the above assumptions are given in Table 1. The mass balance demonstrated that the total salt amount thus calculated overcomes by only $3 \%$ the right one. However, the double salt composition in Table 1 should be viewed as a formal one inasmuch as potassium and ammonium are interchangeable in both alums and Tutton's salt and, at the same time, mixed Tutton's salts, containing two different divalent cations may occur. But, as ammonium largely overcomes potassium (Fig. 7) double salts will contain mostly ammonium as the monovalent ion.

The efflorescence in Tronshart House is also composed of sulfate salts but its composition is less intricate. Among the cations detected in a recrystallized specimen, only ammonium and magnesium are present at large concentrations (57.5 and $28.2 \mathrm{~mol} \%$, respectively, of the total number of cation moles). Certainly, these two ions arise from wood treatment with preservative salts. Potassium (5.6\%), sodium (4.7\%), manganese (2.5\%), zinc $(0.8 \%)$, and calcium $(0.7 \%)$ that are also present, originate most likely from the minerals components of wood and impurities in the preservative salts.

\section{Salt content within the wooden material}

XRF data demonstrated that whatever the occurrence of efflorescence, salts are present in wooden material down to a certain depth. The depth of penetration was assessed by the analysis of drill core samples with focus on the most abundant components in the efflorescence, i.e., ammonium and sulfate. Figure 8 shows the depth-profile of ammonium and sulfate concentration in a drill core

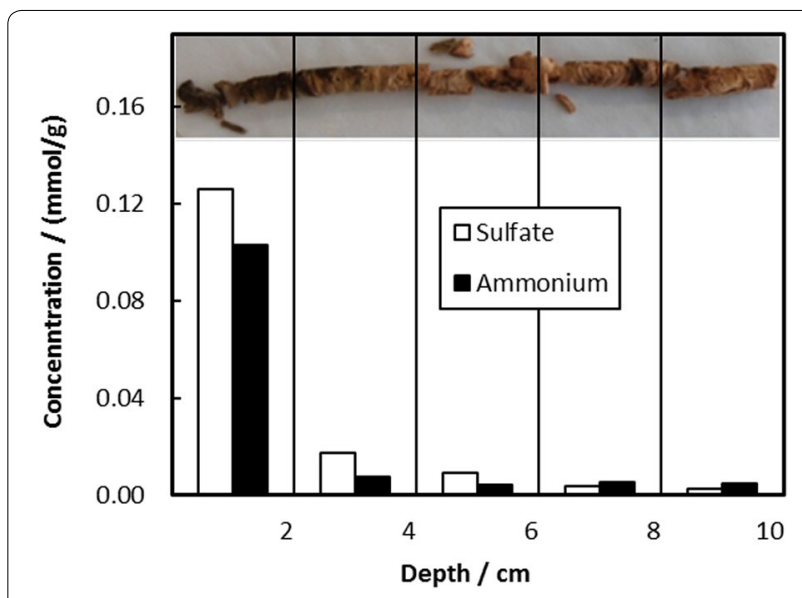

Fig. 8 Sulfate- and ammonium ion depth profiles in an efflorescence-coated log of Aspaas House collected from a wall area coated with efflorescence. It proves that the concentration of each of the above ion is rather high within the first $2 \mathrm{~cm}$ thick layer but decreases sharply with the distance from the surface and practically vanishes beyond a depth of $6 \mathrm{~cm}$. For comparison, in a drill core sample from a recently installed log the sulfate ion content varies around $0.04 \mathrm{mg} \mathrm{g}^{-1}$ all along the core while the ammonium content is below the LOD $(2 \mu \mathrm{mol} / \mathrm{g})$ throughout the whole core sample.

In conclusion, the efflorescence occurs only on wooden material that contains a significant amount of salts within its structure. Most of the salt amount included in wooden material is localized within an about $6 \mathrm{~cm}$ thick layer.

\section{Discussion}

The protocol here envisaged allowed performing a characterization of the efflorescence in the buildings under investigation. On site examinations by XRF led to the identification of a number of chemical elements in the efflorescence and ascertained the occurrence of inorganic salts not only over the wooden material but also within the peripheral wood layer. Laboratory assays of the plain efflorescence brought about supplementary details on the chemical composition by disclosing additional chemical elements and molecular species, and revealing the occurrence of double salts of the alum and Tutton's compound types. Finally, chemical analysis of the recrystallized efflorescence provided an accurate assessment of the ionic composition of the specimen.

Depth profiling of representative ions (ammonium and sulfate in the present case) ascertained the occurrence of the salts within the peripheral layer down to about $6 \mathrm{~cm}$. If these ions are missing from the efflorescence, other indicator ions can be selected and determined by suited methods such as ICP-OE or IC.

The efflorescence in Aspaas House consists of inorganic sulfate salts containing the following major cations: ammonium, aluminium, magnesium, zinc, potassium, sodium, and iron. Ammonium accounts for about half of total moles of cations.

In order to ascertain the origin of the efflorescence it would be of interest to look first at the content of inorganic components in wood. A compilation of nutrient content in gymnosperms wood (as mass \% of dry matter) shows the following average figures for metal ions: calcium, $0.097 \pm 0.101$, potassium, $0.080 \pm 0.120$, and magnesium, $0.019 \pm 0.012$ [35]. Besides the nutrient elements (nitrogen, phosphorus, potassium, calcium, magnesium), iron, copper, zinc, sodium and manganese are present at the ppt concentration level in wood [21]. Consequently, the main components of the efflorescence cannot be of biogenic origin but arise rather from the products of a preservation treatment applied to the wooden material. 
Most likely, the treatment was applied to the building elements before they were re-assembled on the museum site at the beginning of the twentieth century. At that time, impregnation of museum wood artifacts with inorganic biocides and fire retardants was a well-established practice [5].

The most likely cause of efflorescence seems to be water leakage at a not-recorded date, probably due to roof damage. Leaking water penetrated the wood and dissolved the salts inside forming a salt solution contained within a thin layer at the surface. Subsequent water evaporation and salt crystallization occurred after stopping the water leakage.

According to data in Table 1, most of the efflorescence in Aspaas House consists of double sulfate salts of the alum and Tutton's salt types. However, except for potassium alum and ammonium iron sulfates, which were available as industrial products at the moment of house reassembling, other double sulfates cannot originate from the salt blend applied to logs. More probably, the original salt mixture consisted mostly of simple sulfate salts that generated double salts thereafter, during the crystallization process. The chemical composition of the efflorescence suggests that the impregnation mixture had the following composition (inferred content is given in mass \% for each salt): ammonium sulfate $\left(\left(\mathrm{NH}_{4}\right)_{2} \mathrm{SO}_{4} ; 30\right)$, aluminium sulfate $\left(\mathrm{Al}_{2}\left(\mathrm{SO}_{4}\right)_{3} \cdot 18 \mathrm{H}_{2} \mathrm{O}\right.$; 15), magnesium sulfate $\left(\mathrm{MgSO}_{4} \cdot 7 \mathrm{H}_{2} \mathrm{O} ; 15\right)$, iron(II) sulfate $\left(\mathrm{FeSO}_{4} \cdot 7 \mathrm{H}_{2} \mathrm{O} ; 15\right)$, zinc sulfate $\left(\mathrm{ZnSO}_{4} \cdot 7 \mathrm{H}_{2} \mathrm{O} ; 10\right)$, sodium sulfate $\left(\mathrm{Na}_{2} \mathrm{SO}_{4} \cdot 10 \mathrm{H}_{2} \mathrm{O} ; 10\right)$, and potassium alum $\left(\mathrm{KAl}\left(\mathrm{SO}_{4}\right)_{2} \cdot 12 \mathrm{H}_{2} \mathrm{O} ; 5\right)$. When such a mixture is dissolved, the large content of ammonium ion renders the solution slightly acidic, thus preventing oxidation of iron (II) [36] as well as the hydrolysis of aluminium and other hydrated cations. Manganese and other low-concentration elements may originate from either mineral components of the wood or impurities in the preservative salt blend.

The composition of the efflorescence in the Tronshart House is less intricate. Its chemical composition suggests that it may contain a Tutton's salt $\left(\left(\mathrm{NH}_{4}\right)_{2} \mathrm{Mg}\left(\mathrm{SO}_{4}\right)_{2} \cdot 6 \mathrm{H}_{2} \mathrm{O}\right)$ but also plain ammonium sulfate.

It was already stated that efflorescence is associated with salt crystallization from a solution contained in a porous substrate. In typical efflorescence, salt-containing solution is constantly supplied by capillary action to the evaporation front so that the front position remains unchanged. Conversely, if moisture reaches the saltcontaining porous substrate either accidentally or by deliquescence, subsequent evaporation will involve only a limited amount of solution. Consequently, salt precipitation may start at the surface as efflorescence and continue inside the material as subflorescence. This is the case of the buildings investigated in this paper.
According to literature data, single salts or mixtures of only a few salts were commonly utilized in the past for wood conservation [5]. The complex composition of the salt formulation applied to the Aspaas House is therefore an intriguing exception. Certainly, this intricate formulation was intended to provide effective protection against both fire and biological degradation. The preservative mixture applied to the material in Tronshart House, which is of a less architectural importance, consisted only of ammonium and magnesium sulfates, probably for economy reasons.

The effectiveness of the treatment can be assessed in terms of toxicity to microorganisms, permanency, retention, and depth of penetration into the wood [37]. It is known that salts of alkali metals, magnesium, and zinc (especially sulfates and chlorides) were applied to wood artifacts for biocidal purpose until the advent of organic biocides [5, 7]. The salt blend applied to the Aspaas wooden material contains sulfates of all the above-mentioned metals. Among the above ions, zinc appears as the most efficient biocide and zinc chloride was widely used as a preservative at the beginning of the twentieth century [4]. At the same time, since magnesium and sodium sulfates were used in the past as fire retardants [5], it may be assumed that these salts were selected in order to offer double protection. However, the permanency of soluble salts is only satisfactory in the indoor where the material is not exposed to water. As expected, XRF data proved that the salts were washed out by precipitation from the outdoor areas. The retention (i.e., the amount of preservative that must be impregnated into a specific volume of wood) seems to be satisfactory as far as the peripheral layer is concerned, but the depth of penetration is rather low.

Fire protection is provided by several components of the applied salt blend. Ammonium sulfate, which is the most abundant salt in the treatment mixture, is a wellknown flame retardant $[38,39]$. At elevated temperature, it decomposes and releases gaseous ammonia and sulfur oxides, which dilute the flammable gases produced by cellulose pyrolysis. At the same time, these gases blanket surfaces and limit the access of atmospheric oxygen to the fiery zone thus reducing the rate of charring [40]. Similar protection is provided by water vapor originating from crystallization water that is abundant in the mixture components.

The above fire protection mechanisms are of physical nature. But flame-retardation action is also provided by a chemical mechanism based on charring via dehydration of cellulose below the flaming temperature. As a result, the amounts of flammable tars and gases decrease and the amount of the much less combustible char increase [40]. Cellulose dehydration is catalyzed by dehydrating 
agents such as sulfuric acid that may form by high temperature decomposition of metal sulfates included in the treatment compound. Cellulose dehydration is also catalyzed by Lewis acids [40] and, among the ions present in the salt blend, the following Lewis acids can be listed in the decreasing order of the hardness parameter [41]: $\mathrm{Na}^{+}>\mathrm{Mg}^{2+}>\mathrm{Fe}^{2+}>\mathrm{Zn}^{2+}>\mathrm{Al}^{3+}$.

As far as the treatment technology is concerned, the above-mentioned depth of penetration suggests a treatment by prolonged immersion (steeping) [4]. Depending on timber condition and provenance, this method is able to secure typically a depth of 5-30 $\mathrm{mm}$ [42] which agrees with the penetration determined for the investigated material. In terms of costs and benefits, such an immersion treatment is very convenient [43].

In summary, the complex salt blend applied to the Aspaas House was devised to provide both fire and biological degradation protection. Both well-established empirical knowledge and current theoretical approaches prove that this salt mixture is very efficient as a flame retardant.

Besides the favorable protective effect, possible impairment of wood tissue due to salt preservatives cannot be ruled out. The salt deposit may undergo deliquescence if the relative humidity in air ( $\mathrm{RH})$ overcomes the deliquescence threshold, $\mathrm{RH}_{0}$. Alternating deliquescence-efflorescence cycles may occur and cause stress within the porous substratum [44]. Besides, moisture produced by deliquescence may stimulate the apparition of fungi. As a rule, for a blend of deliquescent substances, the $\mathrm{RH}_{0}$ will be lower than that of each component, which prompts deliquescence to occur at lower RH [45]. However, this effect is less marked in the presence of a common ion [46], as it occurs in the system here investigated in which sulfate is the single anion.

Another problem arising from moisture is the chemical degradation due to acidity produced by metal ion hydrolysis as it was documented in the case of both archaeological waterlogged wood, and fresh wood treated with potassium alum [47].

Wood material, exposed to salt contamination from environment, experienced degradation of the middle lamella between cells, which caused the remaining cells wall layers to separate. As a result, wood fibers are released and wet wood appears as if the surface cells have been pulped. This process was noticed in polar marine environment [48] as well in an abandoned saltpeter work site [49]. The degradation mechanism is not yet known but it was presumed that in the presence of moisture, the dissolved salts would cause a high $\mathrm{pH}$. Consequently, a chemical attack on lignin would occur in a process that could be comparable to the process of alkali pulping of wood. However, this kind of degradation cannot occur in the buildings here investigated since the large content in ammonium prevents $\mathrm{pH}$ to shift to the alkaline range.

Making a full assessment of the health hazard of salt efflorescence is beyond the scope of this work. Actually, a rigorous assessment is impossible because no safety data are available for all double sulfate salts included in the efflorescence. However, as health hazard is due rather to the constituent ions than to the salt itself, some inference can be made from security data sheets of presumed components of the original salt mixture. Accordingly, these salts are not critically hazardous but it is advisable to avoid any kind of exposure to the efflorescence material. Although this material is not volatile, absorption in the human body may occur by inhalation of contaminated dust particles and ingestion via mucociliary clearance [50]. Considering the large specific surface of the efflorescence, this risk should not be ignored at all, particularly if cleaning by mechanical procedures is attempted.

Removal of the efflorescence would be beneficial for the aspect, and to reduce health hazards and risks of wood degradation. Some of the cleaning techniques reviewed in [7] appear suitable in this case. The simplest one is the mechanical procedure using vacuum cleaners fitted with HEPA filters. As the efflorescence shows poor adhesion to the wood, it could be removed in this way but the salts incorporated in the wood will persist. Removal of both efflorescence and incorporated salts could be achieved by the vacuum washing process $[51,52]$. This approach is more costly and laborious but such a deep-cleaning treatment eliminates the risk of efflorescence return and wood degradation under the effect of incorporated salts.

\section{Conclusion}

This paper introduces a protocol for the characterization of inorganic salts efflorescence in wooden buildings. This protocol includes (1) on site chemical analysis by XRF, (2) laboratory investigation of the plain efflorescence by optical and electron microscopy, infrared spectrometry, EMPA and XRF, (3) chemical analysis of purified efflorescence by ICP-AES, IC, and spectrophotometry, and (4) depth profiling of key ions in wooden material. It allows achieving a characterization of the efflorescence from the standpoint of morphology, chemical-, and mineralogical composition. If present, a hidden subflorescence-type salt deposit can easily be identified by chemical analysis of wood cores or, in a non-invasive way, by XRF spectrometry. With minor modifications, this procedure can be applied to the analysis of salt efflorescence on archaeological wooden artifacts.

This protocol was applied to the investigation of efflorescence in ancient timber houses of the Sverresborg Trøndelag Folk Museum in Trondheim, Norway. It was found that the efflorescence, which is present in two of the investigated buildings, consists mostly 
of hydrated double sulfate salts. The efflorescence in Aspaas House includes both Tutton's compounds and alum salts. The main components of this mixture are tschermigite $\left(\mathrm{NH}_{4} \mathrm{Al}\left(\mathrm{SO}_{4}\right)_{2} \cdot 12 \mathrm{H}_{2} \mathrm{O}\right)$, potassium alum $\left(\mathrm{KAl}\left(\mathrm{SO}_{4}\right)_{2} \cdot 12 \mathrm{H}_{2} \mathrm{O}\right)$, mohrite $\left.\left(\left(\mathrm{NH}_{4}\right)_{2} \mathrm{Fe}\left(\mathrm{SO}_{4}\right)_{2} \cdot 6 \mathrm{H}_{2} \mathrm{O}\right)\right)$, boussingaultite $\left.\left(\mathrm{NH}_{4}\right)_{2} \mathrm{Mg}\left(\mathrm{SO}_{4}\right)_{2} \cdot 6 \mathrm{H} 2 \mathrm{O}\right)$, and zinc ammonium sulfate $\left.\left(\mathrm{NH}_{4}\right)_{2} \mathrm{Zn}\left(\mathrm{SO}_{4}\right)_{2} \cdot 6 \mathrm{H}_{2} \mathrm{O}\right)$. As both alums and Tutton's salts can form isomorphous series, the presence of mixed crystals structures cannot be excluded.

The origin of the efflorescence is a treatment with inorganic salts intended to protect the wood against fire and biological degradation. The cause of this efflorescence was water leakage which led to salt dissolution and subsequent crystallization at the surface of the porous wood substratum. Although such an accident can be avoided, the risk of efflorescence on wood treated with inorganic salts is still worth consideration. A spontaneous and more frequent cause of efflorescence is deliquescence, which can provide moisture for salt dissolution. Variations in relative humidity of the inner atmosphere will cause dissolution/crystallization cycles leading to efflorescence.

Knowledge of efflorescence properties allowed estimating its health hazards and assessing possible remediation techniques.

The story of an historical building does not stop after being taken in custody by an institution. Conversely, as stated by Nystu [14], any kind of architectural modification done during the relocation to the museum or afterwards, is a part of the development story of that building. However, besides rebuilding and restoration, preservation treatment of wooden material could also have been a major earlier undertaking. Hence, the chemical research of products of such a treatment provides new details on the history of the building and sheds light upon conservation techniques used in the past.

\section{Abbreviations}

BSE: back-scattered electrons imaging: EPMA: electron probe microanalysis: FT-IR: Fourier transform-infrared spectrometry; IC: ion chromatography; ICPAES: inductively coupled plasma atomic emission spectrometry; LOD: limit of detection; XRD: X-ray diffraction; XRF: X-ray fluorescence spectrometry.

\section{Authors' contributions}

EC: literature search, in situ investigations, sample collection, sample preparation for analysis, investigations by FT-IR, XRD, BSE, EPMA, data processing and interpretation, editing the manuscript. FGB: literature search, in situ investigations, sample collection, data processing and interpretation, editing the manuscript. AB: chemical analysis by ICP-OES, spectrophotometry and IC, data processing and interpretation. All authors read and approved the final manuscript.

\section{Authors' information}

E.C. has an MSc in Analytical Chemistry from the University of Bologna, Italy. He is currently a Ph.D. candidate in Chemistry at the Norwegian University of Science and Technology (NTNU). His research projects focus on the characterization of artistic materials using non-invasive and non-destructive analytical techniques.
F.-G. B. has research experience in chemistry of stable isotopes, electroanalytical chemistry, surface electrochemistry, chemical sensors, atomic spectrometry, water analysis and physico-chemical methods applied to the investigation of cultural heritage artifacts.

A.B. has a Ph.D. degree in Analytical Chemistry with experience in electroanalytical chemistry, and surface electrochemistry. She is the Manager of the Laboratory Unit at Geological Survey of Norway (NGU). Her current fields of interest encompass atomic spectrometry, ion chromatography, analysis of ground water and geological materials, processing of geological samples, laboratory management, and quality assurance in the analytical laboratory.

\section{Author details}

${ }^{1}$ Department of Chemistry, Faculty of Natural Science and Technology, NTNU (Norwegian University of Science and Technology), 7491 Trondheim, Norway. ${ }^{2}$ Geological Survey of Norway (NGU), Leiv Eirikssons vei 39, 7040 Trondheim, Norway.

\section{Acknowledgements}

The author are much obliged to Mrs. Lisa Monner (conservator-restaurator) and Mr. Thor-Aage Heiberg (Head, Buildings and Preservation Division), both with Sverresborg Trøndelag Folk Museum, Trondheim, Norway, for kind support with in situ investigations and sample collection. Dr. Kidane Fanta Gebremariam is gratefully acknowledged for assistance with XRD and SEMEPMA analyses.

\section{Competing interests}

The authors declare that they have no competing interests.

\section{Funding}

This work was supported by the Department of Chemistry, Norwegian University of Science and Technology (NTNU), Sverresborg Folk Museum in Trondheim, and Anders Jahres Fund for Chemistry and Marine Technology.

Received: 23 May 2016 Accepted: 2 August 2016

Published online: 04 October 2016

\section{References}

1. Čapek K. Travels in the north. London: Allen \& Unwin; 1939

2. Lebow ST. Wood preservation. Wood handbook-Wood as an engineering material. General technical report FPL-GTR-190. Madison: U.S. Department of Agriculture, Forest Service, Forest Products Laboratory; 2010.

3. Richardson BA. Wood preservation. 2nd ed. Hoboken: Taylor and Francis; 2002

4. Eaton RA, Hale MDC. Wood: decay, pests, and protection. London: Chapman \& Hall; 1993.

5. Unger A, Schniewind AP, Unger W. Conservation of wood artifacts: a handbook. Berlin: Springer; 2001.

6. Charola AE, Koestler RJ, editors. Pesticide mitigation in museum collections: science in conservation: proceedings from the $\mathrm{MCl}$ workshop series. Washington, DC: Smithsonian Institution Scholarly Press; 2010.

7. Unger A. Decontamination and "deconsolidation" of historical wood preservatives and wood consolidants in cultural heritage. J Cult Herit. 2012;13(3):S196-202.

8. Espinosa-Marzal RM, Scherer GW. Advances in understanding damage by salt crystallization. Acc Chem Res. 2010;43(6):897-905.

9. IUPAC compendium of chemical terminology — the Gold Book: international union of pure and applied chemistry; 2014. http://goldbook.iupac. org/. Accessed 10 May 2016.

10. Charola AE. Salts in the deterioration of porous materials: an overview. J Am Inst Conserv. 2000;39(3):327-43.

11. Brocken H, Nijland TG. White efflorescence on brick masonry and concrete masonry blocks, with special emphasis on sulfate efflorescence on concrete blocks. Constr Build Mater. 2004;18(5):315-23.

12. Kim DW, Kim CW, Han SH, Chung YJ, Han GS. Flame retardant treatment's effects and detection method on wooden buildings' pigment layer. J Korean Wood Sci Technol. 2014:42(4):393-406.

13. Aspaasgården. Røros: Sverresborg Trøndelag Folk Museum. http://sverresborg.no/utstillinger/friluftsmuseet/bygda/rorosgardene/. Accessed 22 Aug 2016. 
14. Nystu E. Aspåsgården fra Røros. Bygningstradisjoner i grensetrakter. Östersund: Jamtli, Jämtlands läns museum; Stiftelsen Domkirkeodden; 2007. p. 229-40.

15. Water analysis - determination of ammonia-nitrogen. Norwegian Standard NS 4746:1975. Oslo: Standard Norge; 1975

16. Water quality - determination of ammonium — part 1: manual spectrometric method. ISO 7150-1:1984

17. Gibson LT, Cooksey BG, Littlejohn D, Tennent NH. Investigation of the composition of a unique efflorescence on calcareous museum artifacts. Anal Chim Acta. 1997;337(3):253-64.

18. Linnow K, Halsberghe L, Steiger M. Analysis of calcium acetate efflorescences formed on ceramic tiles in a museum environment. J Cult Herit. 2007:8(1):44-52.

19. Charlot $G$. Analyse qualitative rapide des cations et des anions. Paris: Dunod; 1977.

20. Veran-Tissoires S, Marcoux M, Prat M. Discrete salt crystallization at the surface of a porous medium. Phys Rev Lett. 2012;108(5):054502.

21. Rowell RM, Pettersen R, Tshabalala MA. Cell wall chemistry. In: Rowell RM, editor. Handbook of wood chemistry and wood composites. Boca Raton: CRC Press; 2013. p. 33-72

22. Nakamoto K. Infrared and Raman spectra of inorganic and coordination compounds, part A, theory and applications in inorganic chemistry. Hoboken: Wiley; 2009.

23. Povarennykh AS. Use of infrared-spectra for determination of minerals. Am Mineral. 1978;63(9-10):956-9.

24. Farmer VC, editor. The Infrared spectra of minerals. London: The Mineralogical Society; 1974

25. Ross SD. Sulphate and other oxy-anions of Group VI. In: Farmer VC, editor. The Infrared spectra of minerals. 4. London: The Mineralogical Society; 1974. p. 423-44

26. Barashkov MV, Komyak Al, Shashkov SN. Vibrational spectra and structure of potassium alum $\mathrm{KAl}\left(\mathrm{SO}_{4}\right)_{2} \cdot 12\left[\left(\mathrm{H}_{2} \mathrm{O}\right)_{x} \cdot\left(\mathrm{D}_{2} \mathrm{O}\right)_{1-\mathrm{x}}\right]$. J Appl SpectrosC. 2004:71(3):328-33.

27. Brown RG, Ross SD. Forbidden transitions in infra-red spectra of tetrahedral anions. 6. Tuttons salts and other double sulphates and selenates. Spectrochim Acta. 1970;26(4):945-53.

28. Marinova D, Georgiev M, Stoilova D. Vibrational behavior of matrix-isolated ions in Tutton compounds. I. Infrared spectroscopic study of $\mathrm{NH}_{4}^{+}$ and $\mathrm{SO}_{4}{ }^{2-}$ ions included in magnesium sulfates and selenates. J Mol Struct. 2009:929(1-3):67-72.

29. Marinova D, Georgiev M, Stoilova D. Vibrational behavior of matrix-isolated ions in Tutton compounds. V. Infrared spectroscopic study of $\mathrm{NH}_{4}^{+}$ and $\mathrm{SO}_{4}{ }^{2-}$ ions included in zinc sulfates and selenates. Solid State Sci. 2010;12(5):765-9.

30. Ryskin Yl. The vibration of protons in minerals: hydroxyl, water and ammonium. In: Farmer VC, editor. The Infrared spectra of minerals. 4 London: The Mineralogical Society; 1974. p. 423-44.

31. Wagner EL, Hornig DF. The vibrational spectra of molecules and complex ions in crystals. 3. Ammonium chloride and deutero-ammonium chloride. J Chem Phys. 1950;18(3):296-304.

32. Ammonium alum 2016. http://sdbs.db.aist.go.jp/sdbs/cgibin/direct_ frame_top.cgi. Accessed 03 Mar 2016.

33. Ramasamy G, Bhagavannarayana G, Madhurambal G, Meenakshisundaram S. Crystal growth, structure, crystalline perfection and characterization of zinc magnesium ammonium sulfate hexahydrate mixed crystals $\mathrm{Zn}_{\mathrm{x}} \mathrm{Mg}_{(1-\mathrm{x})}\left(\mathrm{NH}_{4}\right)_{2}\left(\mathrm{SO}_{4}\right)_{2} \cdot 6 \mathrm{H}_{2} \mathrm{O}$. J Cryst Growth. 2012;352(1):137-42.
34. Shannon RD. Revised effective ionic-radii and systematic studies of interatomic distances in halides and chalcogenides. Acta Cryst A. 1976;32(SEP1):751-67.

35. Meerts P. Mineral nutrient concentrations in sapwood and heartwood: a literature review. Ann For Sci. 2002:59(7):713-22.

36. Stumm W, Lee GF. Oxygenation of ferrous iron. Ind Eng Chem. 1961:53(2):143-6.

37. Ibach RE. Biological Properties of Wood. In: Rowell RM, editor. Handbook of wood chemistry and wood composites. Boca Raton: CRC Press; 2013. p. 99-126.

38. Goldstein IS. Degradation and protection of wood from thermal attack. In: Nicholas DD, Loos WE, editors. Wood deterioration and its prevention by preservative treatments: vol I: degradation and protection of wood. New York: Syracuse University Press; 1973. p. 307-40

39. White RH, Dietenberger MA. Fire safety of wood construction. Wood handbook-wood as an engineering material. General technical report FPL-GTR-190. Madison: U.S. Department of Agriculture, Forest Service, Forest Products Laboratory; 2010.

40. Kandola BK, Horrocks AR, Price D, Coleman GV. Flame-retardant treatments of cellulose and their influence on the mechanism of cellulose pyrolysis. J Macromol Sci Rev Macromol Chem Phys C. 1996;36(4):721-94.

41. Parr RG, Pearson RG. Absolute hardness: companion parameter to absolute electronegativity. J Am Chem Soc. 1983;105(26):7512-6.

42. Bigorra Llosas J, Höfer R, Fabry B, Molitor J-P, Merlet S, Valls R. Use of biocide compositions for wood preservation. USA. patent US 7,959,723 B2. 2011.

43. Richardson BA. Wood preservation. 2nd ed. London: E. \& F.N. Spon; 1993.

44. Scherer GW. Stress from crystallization of salt. Cem Concr Res. 2004:34(9):1613-24.

45. Mauer LJ, Taylor LS. Water-solids interactions: deliquescence. In: Doyle MP Klaenhammer TR, editors. Annual review of food science and technology, vol. 1; 2010. p. 41-63.

46. Allan M, Taylor LS, Mauer LJ. Common-ion effects on the deliquescence lowering of crystalline ingredient blends. Food Chem. 2016;195:2-10.

47. Braovac $\mathrm{S}$, Kutzke $H$. The presence of sulfuric acid in alum-conserved wood_origin and consequences. J Cult Herit. 2012;13(3):S203-8.

48. Blanchette RA, Held BW, Farrell RL. Defibration of wood in the expedition huts of Antarctica: an unusual deterioration process occurring in the polar environment. Polar Rec. 2002;38(207):313-22.

49. Ortiz R, Navarrete H, Navarrete J, Párraga M, Carrasco I, Vega EDL, et al. Deterioration, decay and identification of fungi isolated from wooden structures at the Humberstone and Santa Laura saltpeter works: aworld heritage site in Chile. Int Biodeterior Biodegrad. 2014;86:309-16.

50. Turner A. Oral bioaccessibility of trace metals in household dust: a review. Environ Geochem Health. 2011;33(4):331-41.

51. Winkler A, Föckel A, Unger A. Das Vakuumwaschverfahren. Restauro. 2002;108(5):339-43.

52. Püschner K, Föckel A, Unger A, Method for decontamination of organic material objects contaminated with organochloride biocides. Germany patent DE10242048 A1. 2004

\section{Submit your manuscript to a SpringerOpen ${ }^{\circ}$ journal and benefit from:}

- Convenient online submission

- Rigorous peer review

- Immediate publication on acceptance

- Open access: articles freely available online

- High visibility within the field

- Retaining the copyright to your article

Submit your next manuscript at springeropen.com 